\title{
HOW THE SOUTH AFRICAN ELECTORAL SYSTEM WAS NEGOTIATED
}

\author{
By \\ Tom Lodge \\ Professor Tom Lodge is Head of the Department of Political Studies at the \\ University of the Witwatersrand, P O Wits 2050, Johannesburg, South Africa \\ Tel: +27011 717.4369; Fax: +27011 403.7482; e-mail: lodget@social.wits.ac.za
}

\section{SOUth AfricA's Electoral System}

Since 1994 South Africa's National Assembly and its nine regional legislatures have been elected on a list-based system of proportional representation. Proportional representation is a constitutional requirement.

Elections for the Assembly and the legislatures are held simultaneously, though this is not a constitutional stipulation. Voters complete two ballot forms, one for the Assembly, the other for the legislature of the region in which they reside. Ballot forms refer to political parties only. Each party submits lists of candidates for the Assembly and the legislatures before the election. In the case of the Assembly, candidates either appear on a national list or on a list of nominations from the regions. Seats in the 400-member National Assembly and in the regional legislatures are allocated to each party in proportion to its respective share of the vote according to the Droop Quota and Highest Remainder method. In effect the system affords representation to any party that can win 0,25 per cent of the vote - the lowest entry threshold in any proportional representation system. The elections are organised by an Independent Electoral Commission whose five members have, since 1998, been chosen through recommendations to the President by a panel which selects from a group of candidates nominated by an all-party parliamentary committee.

\section{The Negotiating Process}

The essential features of South Africa's electoral system were decided at the Convention for a Democratic South Africa (Codesa), which opened on 20 December 1991 and was attended by eight parties as well as the administrations of the former 'homelands'. Through the activities of five working groups, the Codesa negotiations continued until mid-May 1992 when the African National Congress and the National Party disagreed over the size of the majority which would be required to determine the final Constitution. Subsequently, constitutional discussions proceeded at the Multi-Party Negotiating Forum to which 26 delegations from political parties were invited on 26 April 1993. The electoral system was further elaborated on, though 
its most important principles were not changed, in electoral legislation passed between 1996 and 1998 in conformity with the provisions of the 1996 Constitution. The 1994 election was held under the terms of the 1993 Interim Constitution and accompanying transitional legislation. The 1999 election was organised through the almost identical provisions of the 1996 Constitution and subsequent legislation.

\section{WhAT KIND OF ELECTORAL SYSTEM?}

Settling the arrangements by means of which South Africa's post-apartheid government would be elected was one of the less contentious tasks of those involved in the 1992-1994 constitutional negotiations. This was partly because before the negotiations began three of the main parties favoured the adoption of a system of proportional representation. The Democratic Party (DP) had embraced proportional representation as its official policy for some time. At its Congress in 1991, the DP's Policy Advice Committee recommended a mixed member PR system in which 300 parliamentarians would represent 100 constituencies and 100 would be chosen from national lists.

Very similar proposals were made by the Committee on Constitutional Affairs of the President's Council. The National Party's (NP) constitutional proposals, published during 1991, indicated support for the principle of proportional representation, at least with respect to a first house of parliament, but organised in such a way that candidates would stand for election in specific districts. The vagueness of this qualification was an indication of how little thought most National Party leaders had invested in the details of a new electoral system. The ANC's support for a list-based proportional representation system was evident at least as early as October 1990 when its constitutional specialist, Kader Asmal, presented proposals at a conference attended by experts and party officials. The ANC's policy guidelines, adopted at its National Conference in May 1992, proposed a list-based system of proportional representation, though they also suggested that other systems might prevail at local level.

The ANC's advocacy of PR was based on the recognition that 'the cultural, social and economic diversity of South Africa requires the adoption of an electoral system at all levels which will enable sectoral groups to be adequately represented in decision making' (Asmal, cited in Adam and Moodley 1993, 66). Initially, the ANC was against the use of proportional representation, its experts interpreting its advocacy by the DP and the NP as an expression of 'the ineluctable need of the racial oligarchy to maintain its power'. Uncertainty about its support base may have prompted ANC hostility to PR but by late 1990 polling evidence began to indicate that the ANC enjoyed majority support and hence would win an any election regardless of the representational system (Reynolds 1994, 7).

So, before full negotiations over the electoral system began there was already consensus over a key principle between the most popular party among black South Africans and two of the three white parliamentary parties. The Democrats were 
more concerned about retaining constituency representation than was the National Party, whereas the ANC favoured the system that was eventually enacted in which candidates appear on national and regional party lists. This, of course, maximised the authority of the party leadership - an important consideration in an organisation which was an amalgamation of several quite distinct political traditions, and it also facilitated the inclusion in the party's parliamentary caucus of non-Africans.

\section{How Would Elections Be Organised?}

The technical committee assigned by the Multi-Party Negotiating Forum to the task of designing the electoral administration included nominees of the ANC, NP, DP and the Inkatha Freedom Party (IFP). At the beginning of its deliberations there was disagreement about the role of an electoral commission. The NP favoured a body which would perform a restricted monitoring function with the election itself being run by the Department of Home Affairs. The ANC argued that the Department would not be perceived as neutral and proposed that the commission should administer, adjudicate and monitor elections - a view shared by other former liberation movements as well as by the Democratic Party - and this was the proposal which would ultimately prevail. As a concession to the view that the international community should be involved in running the election, a position adopted by the Pan Africanist Congress (PAC), it was agreed that the commissioners would include five foreigners, though these would not be able to vote in commission decisions. A special task group drafted an Independent Electoral Commission (IEC) Act, which became law in September 1993, and which established a commission which would supervise two directorates, administration and monitoring, as well as a hierarchy of electoral courts. In fact, the Department of Home Affairs would become involved in the election both directly and indirectly. Several of its officials joined the IEC's administrative directorate and the Department itself was charged with issuing voter identity cards under the IEC's supervision.

\section{Disagreements About the Electoral Act}

Agreement was easier to secure on such broad issues as the form of electoral system to be adopted and the question of which body would run the elections than on the finer points of detail. As one commentator noted: 'matters that would affect the election outcome as opposed to matters of principle were the most heatedly debated' (Robertson, in Friedman and Atkinson 1994, 58). Such questions included whether migrant workers could vote outside the provinces in which they normally lived (it was decided, against the ANC's inclinations, that they could if they travelled to their home province). Another divisive issue was the order in which parties should appear on the ballot form: the ANC favoured alphabetical order, but in the end it was decided that the first place would be decided by lottery and all subsequent positions would be filled alphabetically. 
The deepest division in the negotiations that accompanied the drafting of the Electoral Act concerned whether voters would use a single ballot paper or two separate papers - one for the National Assembly and one for the provincial legislature. After much postponement of debate on this issue, within the technical committee it was agreed - on 16 November 1993 at a 'bilateral' encounter between ANC and NP leaders - that a single ballot paper would be used.

Opposition to this option in the technical committee from the Democratic Party which, like other smaller parties, hoped to benefit from split voting, was deflected by a trade-off between the DP and the ANC, with the Democrats conceding the single ballot in return for the acceptance of its proposals about the method of appointment of Constitutional Court judges. The ANC's support for a single ballot was based on the need to make the election as simple as possible and on the perception that one ballot paper would reduce chances of disenfranchisement through spoiled ballots. Its negotiators were also prompted by a less disinterested anxiety that voters might interpret the second ballot as an opportunity to express their second preference. Subsequently though, in a concession to the Freedom Alliance (a coalition of the IFP and white right-wing parties), a double ballot was incorporated in the Act.

\section{Why Was Agreement Possible?}

How was it possible for South African parties to arrive at an agreement about an electoral system which, as all participants in the negotiations knew, would on its adoption result in dramatic political changes? The political consensus reached at the Multi-Party Negotiating Forum was all the more remarkable because it was not a consequence of any external compulsion.

The first answer to this question is that the definition of the electoral system was only one element of the constitutional settlement and gains which may have been achieved by one party at the expense of others in the negotiations over elections were often balanced by concessions in other spheres. An indispensable condition of the National Party accepting universal suffrage based on a common voters' roll - an acceptance which itself represented a sharp movement away from positions it had held as late as 1988 - was the provision of a term of executive power-sharing in which parties which won more than 5 per cent of the vote would enjoy Cabinet representation in proportion to their electoral support. Similarly, the Afrikaner right and the IFP were persuaded to support the settlement because of its regional or federal characteristics which, in Inkatha's case, held out a realistic prospect of executive power. Smaller parties which could not hope to control even regional governments could nevertheless derive satisfaction over the degree to which a Bill of Rights placed limits on the exercise of executive authority as well as the extent to which the principles they had helped to write into a transitional constitution would guide the deliberations of a Constitutional Assembly between 1994 and 1996. Finally, the status of the initial agreement as a transitional undertaking which could be 
altered, at least in detail, when parliament convened itself as a constitutional assembly after the election, probably helped to broaden support within all parties for the arrangements.

The second reason why a settlement could be negotiated was that the most important parties recognised the desirability of making concessions. At the inception of the Codesa negotiations the participants were able to sign a wideranging declaration of intent. By 1990, ANC strategists had acknowledged that they were in no position to expand the scope of their military operations. In any case, since 1989 when it issued its Harare Declaration spelling out its preconditions for a negotiated settlement, the organisation's leaders had, in principle, embraced the option of such a settlement. Growing confidence in the extent of its popularity after 1990 assured the ANC's leaders that they would predominate in any powersharing arrangements they might have to concede in negotiations.

For the National Party and the South African Government, the experience of negotiating a politically liberal and socially conservative dispensation in Namibia in 1989 was an important source of encouragement. While it is conceivable that when President F W de Klerk lifted the ban on the liberation movements in February 1990 he may have hoped that a coalition of conservative parties, white and black, might out-poll the ANC in elections, it is unlikely that NP planners believed this in 1993, when the intricacies of the electoral system began to be designed.

By the end of 1993, with the NP's pollsters telling government leaders that their electoral support was shrinking rapidly, resolving the constitutional debates became an urgent priority. The political violence which both accompanied and interrupted negotiations, though partly a consequence of government-sanctioned efforts to disrupt the ANC's following, began to assume such a scale that they became an important incentive to make concessions. Accurate information about potential electoral support persuaded leaders of both the ANC and the NP to adopt conciliatory positions on key issues in the negotiations. There were also issues on which the interests of the two main parties coincided - for example, the adoption of national list-based proportional representation or a single ballot or, after March 1993, the danger of the negotiations themselves becoming too protracted.

A third factor that facilitated agreement was the negotiation procedures themselves. While all parties were represented equally at Codesa and the MultiParty Negotiating Forum, in practice not all were treated equally. Ideally, decisions would be reached through general consensus - and if this proved impossible the chairperson of the forum would have to decide whether there was at least 'sufficient' consensus. For most purposes, sufficient consensus was equated with agreement between the ANC and the National Party, a practice which encouraged the resolution of key issues in discreet 'bilateral' encounters between representatives of the two parties. It also, however, created the risk that other parties would be alienated or would withdraw from the talks. Indeed, the IFP and the Conservative Party did withdraw from the MPNF. 
Another way in which procedure facilitated agreement was the assignment of the more complicated or politically contentious issues to small groups. The Forum's technical committees were not intended to be politically representative, though parties nominated the committee members. They addressed problems in a technocratic fashion and proposed solutions, which were then presented to the Forum's more representative assemblies as the most plausible options.

A final contribution to the success of the South African negotiations was their broader political setting. They took place in a country in which the existing state retained its legal authority and in which it still held a near monopoly of coercive power. Rebellion against the terms of the settlement was quite evidently not realistic - a factor which made withdrawal from the negotiations an increasingly less attractive option as the extent of ANC/NP agreement grew. Political loyalties were largely concentrated on the party that had dominated South Africa for forty years, or on its most tested adversary. The degree to which political identity in South Africa was institutionalised in a relatively small number of long established and tightly structured political parties obviously simplified negotiations.

This achievement of a negotiated settlement reflected an availability and distribution of resources between parties that is quite unusual in democratising developing countries. It was indicative of a relatively developed and diversified economy as well as of the scale of foreign support to certain political parties. Finally, even the most sectional parties - including "homeland"-based organisations and the white right - did not differ from the main protagonists on broad issues of citizenship and national loyalty. All professed to be South African and recognised each other as compatriots. Even ethnic nationalists did not seriously contest the fact that South Africa should be governed as a unitary state.

\section{REFÉRENCES}

Adam, H. and K. Moodley. 1993. The Negotiated Revolution. Johannesburg: Jonathan Ball.

Davenport, T. R. H. 1998. The Birth of a New South Africa. Toronto: University of Toronto Press.

De Villiers, B. 1994. Birth of a Constitution. Kenwyn: Juta and Co.

Friedman, S. and D. Atkinson. 1994. 'The Small Miracle'. South African Review 7. Johannesburg: Ravan Press.

Rantete, J. 1998. The African National Congress and the Negotiated Settlement in South Africa. Pretoria: J L Van Schaik.

Reynolds, A. 1994. Election'94 South Africa. Cape Town: David Philip.

Spitz, R. with M Chaskalson. 2000. The Politics of Transition. Johannesburg: Witwatersrand University Press. 